\title{
ON CHANGES OF SEA TEMPERATURE IN THE ENGLISH CHANNEL
}

\author{
By A. J. SOUTHWARD \\ The Plymouth Laboratory
}

(Text-figs. I-5)

In a series of papers dealing with changes in the distribution of intertidal animals around Britain, and especially along the English Channel, attention was drawn to some local aspects of the general warming-up of sea and air that has taken place in the last 50 years (Southward \& Crisp, 1954, 1956; Crisp and Southward, 1958). In the first of these papers smoothed values of annual mean air temperature at Plymouth Hoe, and sea surface temperature of the southern Celtic Sea were given, the latter values being based on Smed (1952). The graphs showed a rise of about $\mathrm{I}^{\circ} \mathrm{C}$ in the air temperature and $0.5^{\circ} \mathrm{C}$ in sea temperature during 50 years.

More recently Cooper (1958) has tabulated the monthly mean sea temperatures for Plymouth Sound, based on three times a week readings taken below the Hoe by the Plymouth City Meteorologist. He interprets the figures as showing a rise of about $0.3^{\circ} \mathrm{C}$, but does not give the annual means for the whole period. Annual means may not illustrate fully the effect of a very cold spring and very hot summer in the same year (e.g. 1947) but they do allow rapid comparison for biological purposes, and have considerable significance when resident or sedentary perennial species are being studied, whether they are pilchards or barnacles, for example.

In view of the increases in temperature already noted it would be surprising if a similar rise was not found at International Station EI, which has been worked, with some gaps, since 1903. Some monthly values for this station were given by Atkins \& Jenkins (I952), but they showed no long-term trend. The apparent absence of any change may well have been due to the use of the integral mean of the whole water column; a dubious procedure for temperature. However, Cooper (1958), after remarking that he himself had failed to find any evidence of long-term changes at $E_{1}$, points out that there are inevitably many sources of bias in the raw data, which requires tedious treatment to make it statistically reasonable. Such treatment may be possible in the future (Cooper, personal communications), but there is an immediate need for information of use in current investigations of bottom fauna, plankton and other fields. Therefore, I have reassessed part of the EI data, using only the observations of most interest-surface values, for comparison with the 
many surface observations in other areas, and bottom values for use with studies of bottom fauna and deeper living plankton animals.

Most of the actual observations at EI have been published by the International Council, those for the period $192 \mathrm{I}-30$ in the Rapport Atlantique, and those for $1931-38$ and $1947-54$ in the Bulletin Hydrographique. I am indebted to the observers, Mr F. A. J. Armstrong and Mr E. I. Butler, for the later observations which have not yet been published. For each year the temperatures observed each month have been plotted on graph paper, and the points joined together with a slightly smoothed freehand curve (example in

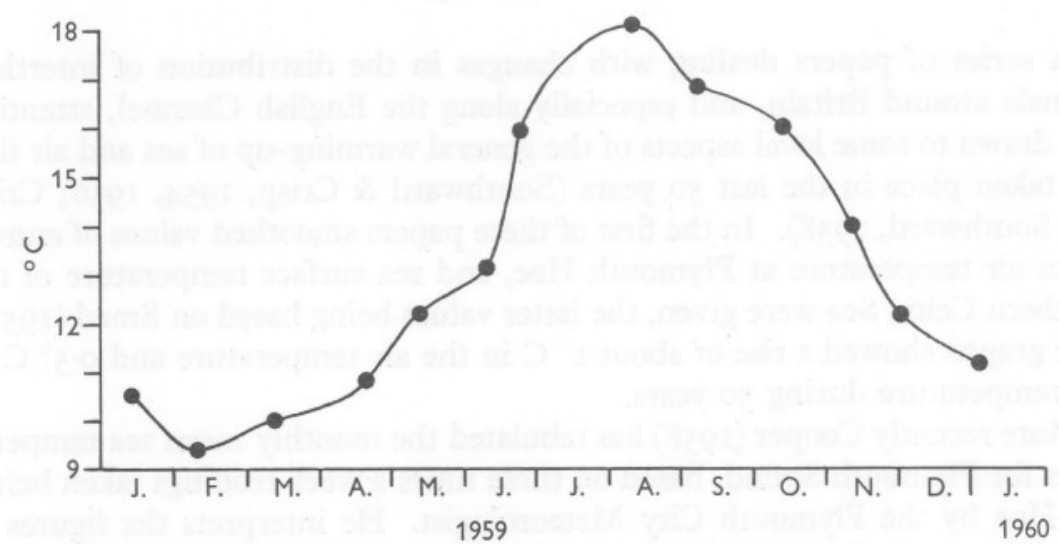

Fig. I. An example of the method used to derive mid-monthly means from the raw data for EI. The points on the slightly smoothed curve are the actual surface temperatures observed in 1959.

Fig. I). From the curves the mid-monthly values were read off, and additional values provided for missing months. The monthly temperatures derived in this way are presented in Table $\mathrm{I}$.

Such treatment is only a little better than use of the raw data for calculating the annual means, and as a way of deriving the monthly values has been described by a colleague as 'fudging'. However, at the moment, it is difficult to find any other manipulation to make the EI results more presentable, except, perhaps, comparison with other stations for surface values, and I believe that it is preferable to abandoning the whole series of observations.

\section{SURFACE TEMPERATURE AT EI}

In addition to Table $\mathrm{I}$, the annual means of surface temperature are plotted in Fig. 2, which also shows the annual means for $1903-27$ worked out by Lumby (I935). Lumby's method involved adjustment to make up for missing months, and there is good agreement for all but one of the overlapping years. 
TABLE 1. DERIVED MID-MONTHLY VALUES OF SEA TEMPERATURE AT INTERNATIONAL STATION EI (LONG. $50^{\circ} 02^{\prime}$ N., LAT. $4^{\circ} 22^{\prime}$ W.)

Surface temperatures (0-0.5 m. depth)

\begin{tabular}{|c|c|c|c|c|c|c|c|c|c|c|c|c|c|c|c|c|}
\hline \\
\hline & I92I & I 922 & I 923 & I 924 & 1925 & I926 & I927 & I928 & 1929 & I930 & I93 I & I932 & I933 & I934 & 1935 & 1936 \\
\hline Jan. & - & II O & $9 \cdot 7$ & $9 \cdot \mathrm{I}$ & $I I \cdot O$ & 10.0 & 9.5 & 10.0 & $9 \cdot 8$ & IO.I & 9.6 & 10.8 & 9.8 & $9 \cdot 2$ & 10.9 & $9 \cdot 4$ \\
\hline Feb. & - & 9.6 & $9 \cdot 4$ & $8 \cdot 4$ & 9.9 & 9.4 & $9 \cdot 4$ & 9.5 & $8 \cdot 8$ & $9 \cdot 2$ & $9 \cdot 2$ & 10.3 & $9 \cdot 3$ & $8 \cdot 3$ & 9.9 & $9 \cdot \mathrm{I}$ \\
\hline Mar. & - & 9.5 & 9.4 & $8 \cdot \mathrm{I}$ & $9 \cdot 3$ & 9.6 & $9 \cdot 3$ & $9 \cdot 5$ & 8.8 & 8.4 & $9 \cdot I$ & 9.4 & $9 \cdot 7$ & $8 \cdot 6$ & 8.9 & 9.4 \\
\hline Apr. & - & $10 \cdot 6$ & 9.9 & $8 \cdot 3$ & $9 \cdot 6$ & 10.2 & 10.4 & 10.0 & 8.9 & $9 \cdot 3$ & 9.6 & $9 \cdot \mathrm{I}$ & 10.2 & 9.6 & $9 \cdot 6$ & 10.0 \\
\hline May & 12.6 & I 2.4 & 10.7 & 10.5 & 10.8 & 10.9 & $12 \cdot 1$ & 12.4 & 11.8 & II $\cdot$ I & 10.9 & II 0 & 10.7 & II'I I & II. 7 & 12.5 \\
\hline June & 15.0 & 13.8 & 12.4 & 13.5 & 13.8 & 13.4 & 13.2 & 13.4 & 14.8 & 15.2 & 13.9 & 14.4 & 12.4 & 13.4 & $14 \cdot 1$ & 13.7 \\
\hline July & 15.9 & 13.0 & 16.5 & 15.9 & 16.1 & I7. I & 15.6 & 17.0 & $17 \cdot 2$ & 15.4 & 15.8 & $17 \cdot 7$ & 14.7 & 15.5 & 16.7 & 14.6 \\
\hline Aug. & 16.2 & 15.0 & 16.7 & 15.1 & 15.5 & $17 \cdot 1$ & 16.8 & 16.0 & 16.5 & $15 \cdot 2$ & 15.2 & 17.7 & 18.7 & 15.6 & 18.2 & 16.5 \\
\hline Sept & 15.8 & 14.9 & 14.9 & 14.2 & 15.7 & 16.9 & 15.4 & 16.9 & 17.0 & 16.4 & 15.0 & 15.6 & 16.8 & 15.2 & 16.2 & 15.9 \\
\hline Oct & 15.5 & 14.0 & 13.0 & 12.9 & 13.7 & 14.8 & 13.8 & 14.3 & I3. I & $14 \cdot \mathrm{I}$ & 14.8 & 13.7 & 15.3 & 13.6 & 13.8 & 14.7 \\
\hline Nov. & 14.2 & II.9 & II .5 & 12.4 & II 6 & 12. 8 & 13.4 & 12.8 & 12.5 & $12 \cdot 8$ & 13.4 & 12.6 & 13.2 & $12 \cdot 3$ & 12.2 & 13.3 \\
\hline Dec. & 12.6 & 10.6 & 10.0 & II 7 & 10.6 & $\mathrm{II} \cdot 2$ & II. 8 & II 3 & II'2 & II $\cdot 4$ & I I 99 & I I $\cdot 4$ & $9 \cdot 9$ & $12 \cdot 3$ & 10.4 & 11.6 \\
\hline \multirow[t]{2}{*}{ Year } & & $12 \cdot 19$ & 12.00 & $11 \cdot 67$ & $12 \cdot 30$ & I2.78 & 12.55 & 12.75 & 12.53 & $12 \cdot 38$ & $12 \cdot 36$ & 12.80 & 12.55 & 12.05 & 12.71 & 12.55 \\
\hline & I937 & I938 & I947 & 1948 & I949 & I950 & I95I & 1952 & 1953 & I954 & 1955 & 1956 & r957 & I958 & 1959 & \\
\hline Jan. & 10.0 & $10 \cdot 2$ & 9.4 & $\mathbf{I I} \cdot \mathbf{I}$ & 10.7 & 10.8 & $9 \cdot 6$ & 10.3 & $9 \cdot 6$ & 10.9 & 9.8 & II $\cdot 0$ & 10.3 & 9.9 & 10.3 & \\
\hline Feb. & $9 \cdot 7$ & 8.9 & $7 \cdot 7$ & 9.9 & 10.0 & 9.4 & 8.8 & $9 \cdot \mathrm{I}$ & 8.5 & $9 \cdot \hat{I}$ & 9.5 & 9.I & 9.7 & $9 \cdot 4$ & $9 \cdot 4$ & \\
\hline Mar. & 9.6 & $9 \cdot 1$ & $7 \cdot 9$ & $9 \cdot I$ & 10.3 & 10.1 & 8.7 & $9 \cdot I$ & $8 \cdot 5$ & $9 \cdot 2$ & $7 \cdot 7$ & 8.6 & 10.4 & 8.9 & 10.0 & \\
\hline Apr. & 10.0 & 9.8 & $9 \cdot 4$ & 10.2 & 10.9 & 10.7 & $9 \cdot 4$ & 9.9 & $8 \cdot 7$ & $9 \cdot 7$ & 8.6 & 9.6 & 10.6 & 9.8 & 10.7 & \\
\hline May & II. 5 & 10.8 & $11 \cdot 6$ & 10.2 & 11.9 & II 3 & 10.5 & II 17 & 10.8 & II.7 & 10.6 & II $\cdot 9$ & II'S & 10.4 & $12 \cdot 3$ & \\
\hline June & 15.6 & 12.8 & 13.2 & I $2 \cdot \mathrm{I}$ & 14.6 & 14.2 & 12.8 & 14.0 & 13.2 & 14.5 & I3. I & 14.0 & 14.2 & 13.6 & 13.7 & \\
\hline July & 16.2 & 15.6 & 16.8 & 15.8 & 16.6 & 15.7 & 16.4 & 15.9 & 14.9 & 13.3 & 18.5 & 15.5 & I6. I & 16.4 & 17.5 & \\
\hline Aug. & 17.8 & 17.7 & 17.6 & 17.0 & 15.8 & 15.8 & 15.4 & 15.9 & 17.4 & $14 \cdot 2$ & 16.0 & $15 \cdot 2$ & 16.0 & 15.7 & 18.0 & \\
\hline Sept. & 16.3 & 15.6 & 16.3 & 15.8 & 17.4 & 15.0 & 14.6 & 150 & 16.0 & 14.9 & 14.8 & 15.0 & 14.8 & 14.8 & 16.6 & \\
\hline Oct. & 14.8 & 14.0 & 15.0 & 143 & 15.5 & 14.2 & 14.0 & 13.7 & 14.5 & 13.7 & I $4 \cdot$ I & 14.4 & 14.8 & I 4.4 & 15.9 & \\
\hline Nov. & 13.3 & 13.0 & 13.7 & 13.7 & $13 \cdot 3$ & $12 \cdot 7$ & 12.9 & 12. 4 & 13.0 & 13.0 & $13 \cdot 1$ & 12.9 & 12.7 & 13.7 & 13.7 & \\
\hline Dec. & II $\cdot 6$ & $12 \cdot 7$ & 12.4 & 12.4 & II.7 & 10.9 & $11 \cdot 7$ & 10.9 & $12 \cdot 7$ & $\mathbf{I} \mathbf{I} \cdot 0$ & I $2 \cdot I$ & $11 \cdot 5$ & II $\cdot 3$ & $12 \cdot 3$ & II $\cdot 5$ & \\
\hline Year & 13.03 & 12.51 & 12.58 & 12.63 & 13.22 & $12 \cdot 56$ & 12.06 & $12 \cdot 32$ & $12 \cdot 31$ & $12 \cdot 10$ & $12 \cdot 32$ & $12 \cdot 39$ & 12.70 & 12.41 & 13.30 & \\
\hline
\end{tabular}

'Bottom' temperatures (60-75 m. depth)

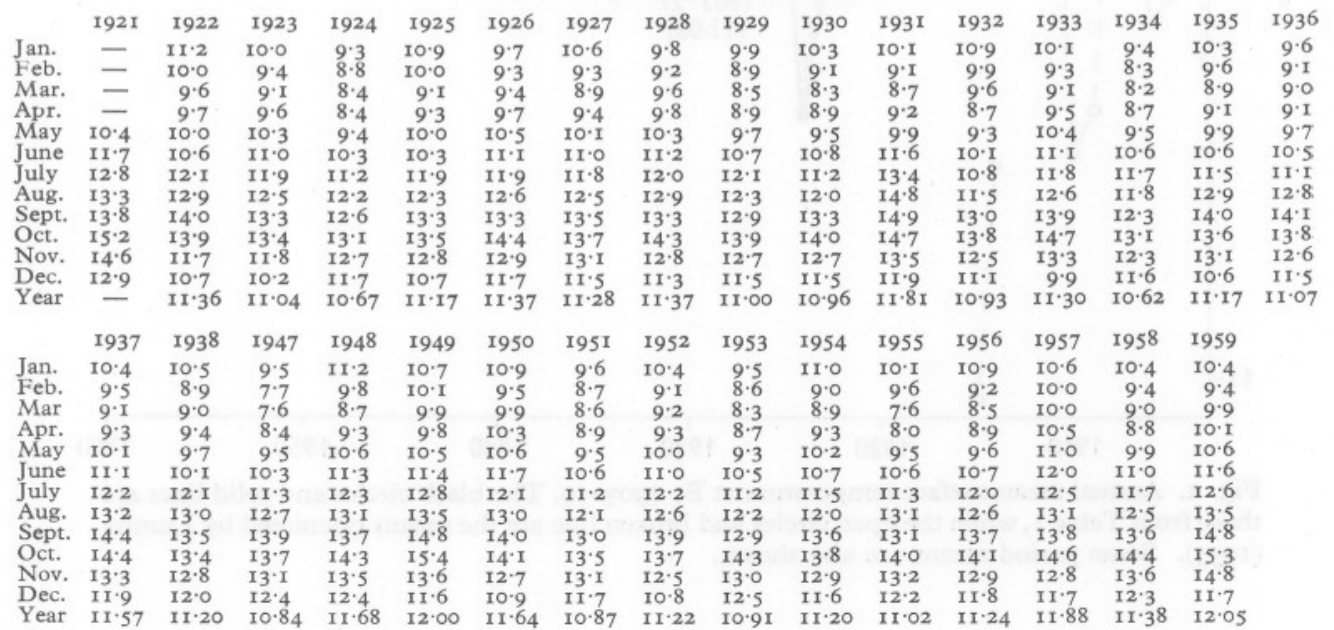

The general trend is obviously upwards. Compared with $1903-27$, the period mean for $1928-59$ is $0.46^{\circ} \mathrm{C}$ higher, an increase of the same order as that found further west in the Celtic Sea (see p. 449). A distinct interruption of the rise occurred in 1951-56: during this 'little cold spell' there was a slight return of the northern barnacle, Balanus balanoides, at many stations in south-west England and elsewhere (Southward \& Crisp, 1956; and unpublished records). However, even in this period the annual means were as 
high as, or higher than, those of the warmest years of I903-II. The upward trend is also displayed in the very warm years. The year I92I was regarded as exceptionally warm for the time (Le Danois, I923; Harvey, I923), but since then we have had at least two warmer years, I949 and 1959. Looking at the graph, one might say that I92I was the first major sign of the warm spell that set in a few years'later, and which appears to be continuing still.

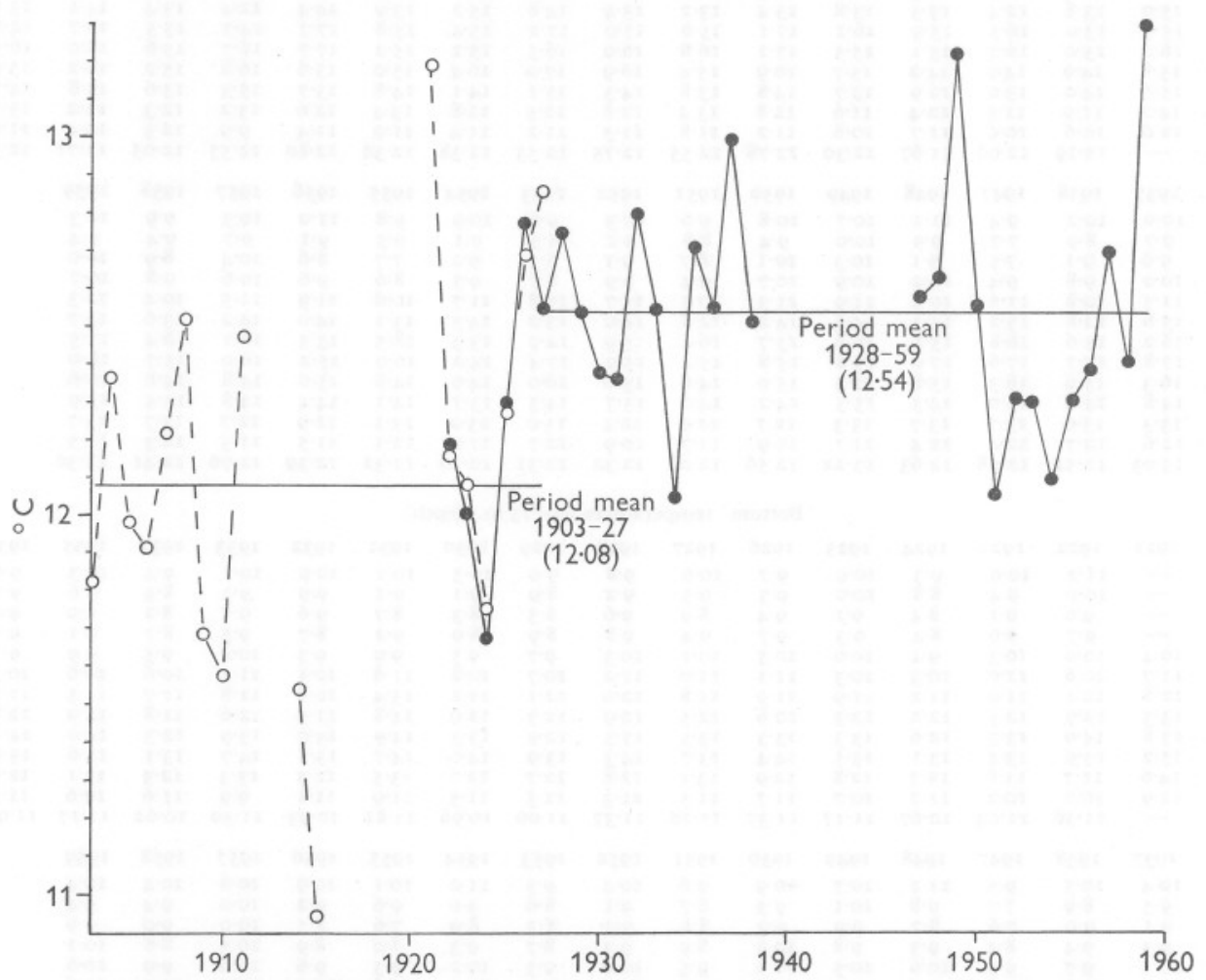

Fig. 2. Annual mean surface temperature at EI 1903-59. The black circles and solid lines are those from Table $\mathrm{I}$, while the open circles and broken line are the means calculated by Lumby (I935). Some period means are also shown.

If we examine the monthly values, the changes do not seem to have been quite so clear cut as with the annual means. The little cold spell mentioned above was marked by a sequence of cold winters (temperatures below $10^{\circ} \mathrm{C}$ from February to April), but in some of these years the summer was hot, which suggests a more continental, or less oceanic, marine climate than in earlier years. A similar trend since the late 1920's might be inferred from the monthly bottom temperatures also (Table I). To contrast with this suggestion we have the generally warm years (e.g. 1949, 1959) when the surface tem- 
peratures in winter (Feb.-Apr.) were higher than the temperatures found in every year before 1939 .

Probably the steadiest trend can be shown in the autumn months. There has been a slow rise in October, November and December, clearly demonstrated by grouping the figures into three periods:

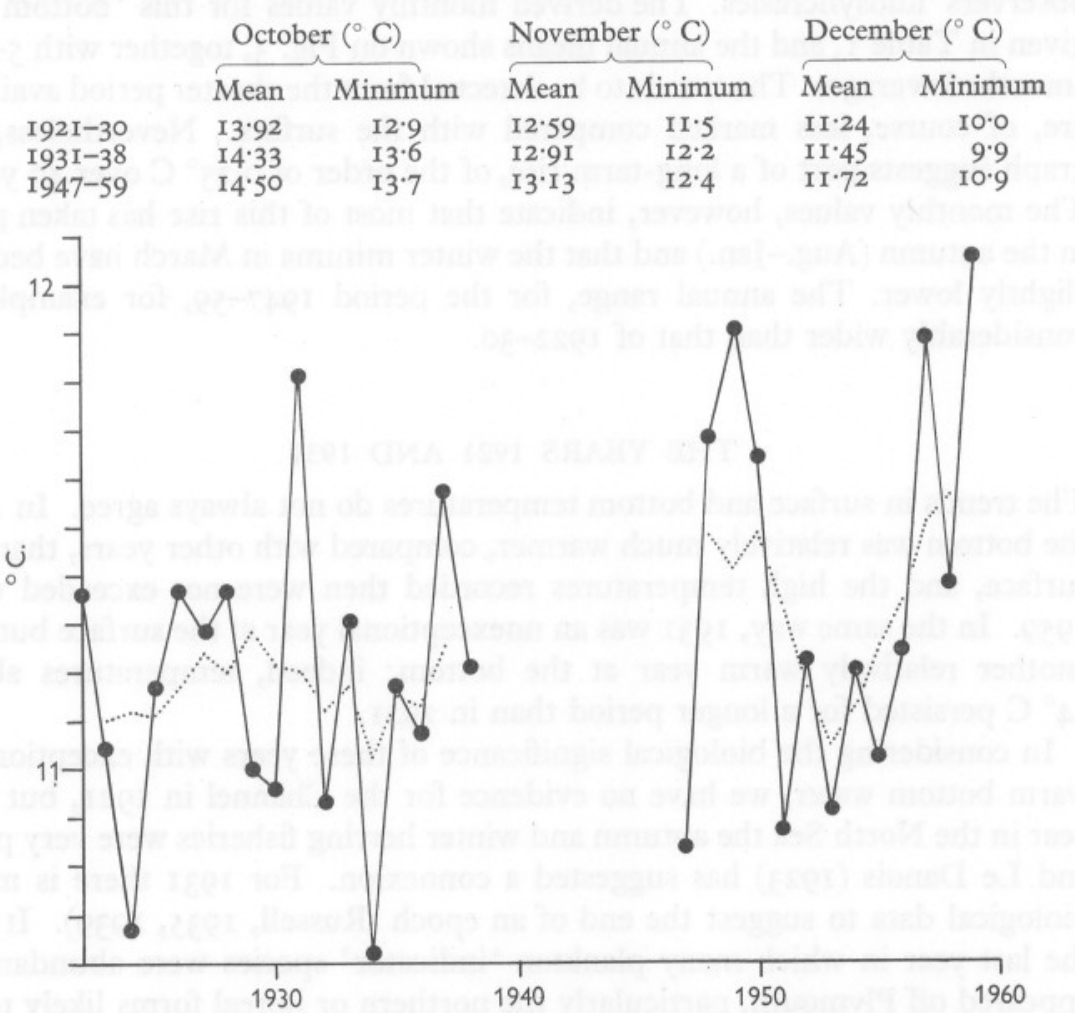

Fig. 3. Annual mean bottom temperature at Er, 1922-59.

The dotted line shows the 5 -year smoothed averages.

Thus there has been a rise of half a degree in the autumn means, and nearly twice this amount in the period minima. This autumn trend appears to be carried over into January, the monthly figures for which also show rises, but only about $0.2-0.3^{\circ} \mathrm{C}$ in this case. The cumulative effect of these increases on winter-spawning fish (the spring-spawners of Russell, 1935, 1939) can only be guessed at, but it is worth noting that Ford (1929) deduced a link between falling sea temperatures at $\mathrm{E}_{\mathrm{I}}$ in the autumn and a successful herring fishery off Plymouth. 


\section{BOTTOM TEMPERATURE AT EI}

From I92I to I959 the recorded depth of the lowest water sample at EI has varied from 60 to $75 \mathrm{~m}$. This is not, of course, due to variation in the sea-bed, but to combinations of inaccurate stationing of the ships, tide, wire angle and observers' idiosyncrasies. The derived monthly values for this 'bottom' are given in Table $\mathrm{I}$, and the annual means shown on Fig. 3, together with 5-year smoothed averages. The trends to be detected from the shorter period available are, of course, less marked compared with the surface. Nevertheless, the graph suggests part of a long-term rise, of the order of $0.25^{\circ} \mathrm{C}$ over 40 years. The monthly values, however, indicate that most of this rise has taken place in the autumn (Aug.-Jan.) and that the winter minima in March have become slightly lower. The annual range, for the period 1947-59, for example, is considerably wider than that of $1922-30$.

\section{THE YEARS 1921 AND 1931}

The trends in surface and bottom temperatures do not always agree. In I92I the bottom was relatively much warmer, compared with other years, than the surface, and the high temperatures recorded then were not exceeded until 1959. In the same way, I93I was an unexceptional year at the surface but was another relatively warm year at the bottom: indeed, temperatures above $\mathrm{I} 4^{\circ} \mathrm{C}$ persisted for a longer period than in $\mathrm{I} 92 \mathrm{I}$.

In considering the biological significance of these years with exceptionally warm bottom water, we have no evidence for the Channel in I92I, but that year in the North Sea the autumn and winter herring fisheries were very poor, and Le Danois (I923) has suggested a connexion. For I93I there is much biological data to suggest the end of an epoch (Russell, I935, I939). It was the last year in which many plankton 'indicator' species were abundant or appeared off Plymouth, particularly the northern or boreal forms likely to be adversely influenced by warmer conditions-Aglantha, Sagitta elegans, and Meganyctiphanes, for example. To judge from the evidence obtained by Ford (to be found in Ford, 1933; Kemp, 1938) there was a practically total failure of recruitment of herring in the Plymouth area in the winter of $1931-32$. This was not due to absence of adults, for considerable landings occurred, though 'running' herring were scarce (Ford, I933). Herring are also northern forms and are likely to be adversely affected, not necessarily directly, by warmer conditions (cf. Russell, 1939). A thorough study of the recorded hydrographical conditions in the second half of I93 I, in relation to the biological changes, would be very rewarding. 


\section{COMPARISON WITH OTHER REGIONS OF \\ THE CHANNEL}

Bowden (1955) has tabulated some annual means and period monthly means of the surface temperatures taken at the Seven Stones Light Vessel, and has shown graphically the annual means for the English Channel as a whole from I903 to I95I. Mr A. J. Lee of the Fisheries Laboratory, Lowestoft, has

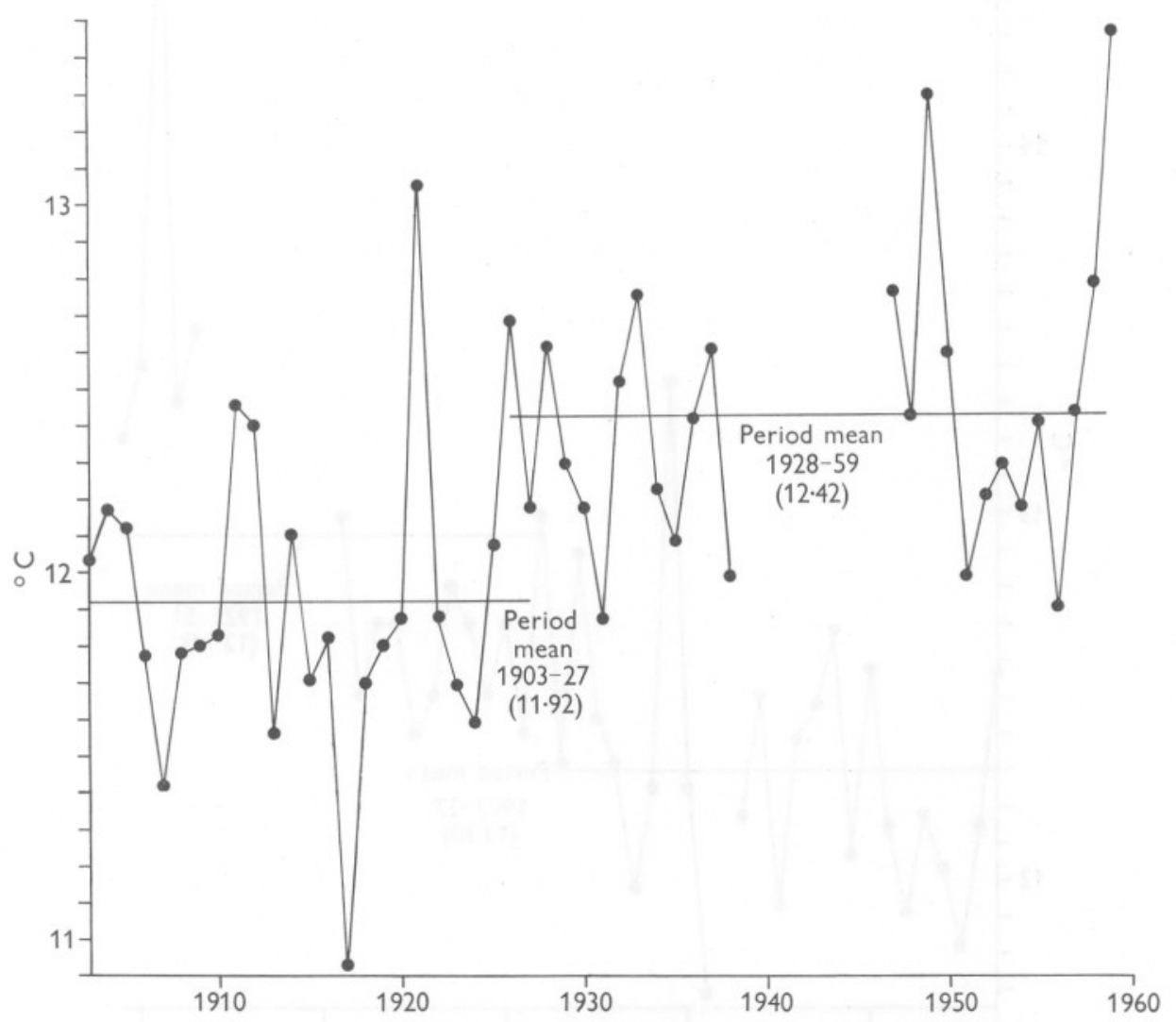

Fig. 4. Annual mean surface temperature at the Seven Stones Light Vessel, 1905-59. From Lumby (1935) and Bowden (1955), with means to 1959 supplied by Mr A. J. Lee.

kindly supplied me with further annual means for the Seven Stones to 1959. He has also supplied additional annual means to I95I for Lumby area 9, for which Lumby (I935) has already published the means from I903 to I927. The annual means for these two stations are shown in Figs. 4 and 5, and it is obvious that the trends already shown for EI are closely paralleled. At the Seven Stones the rise over 50 years has been about $0.5^{\circ} \mathrm{C}$, though the peak 
in I92I was less marked, and the little cold spell of $195 \mathrm{I}-56$ relatively less cold than off Plymouth.

North of Ushant (area 9) the period means show a rise of $0.64^{\circ} \mathrm{C}$, somewhat more than at EI or the Seven Stones. A larger increase than elsewhere is not

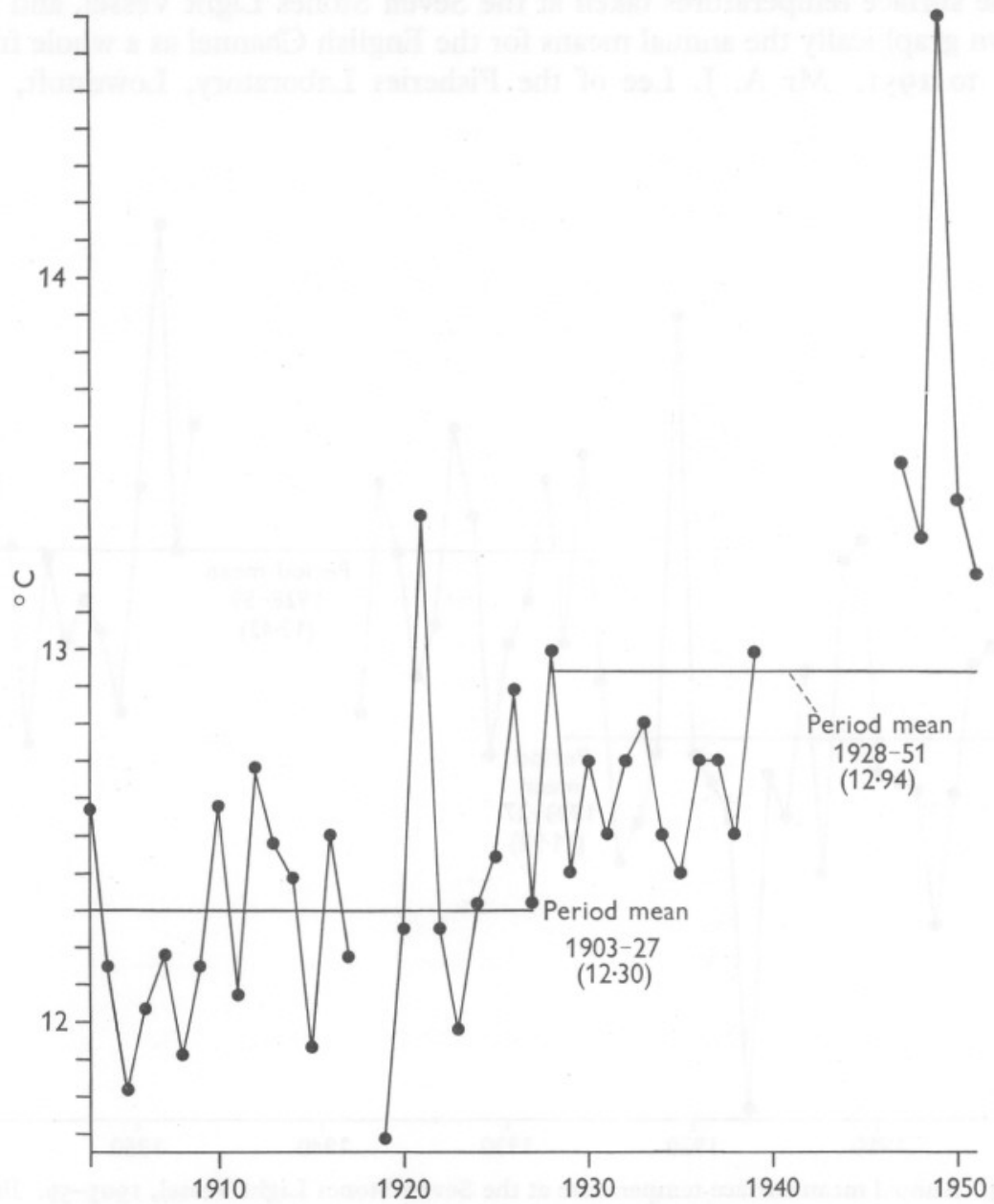

Fig. 5. Annual mean surface temperature in Lumby area 9 (area centred on long. $48^{\circ} 40^{\prime} \mathrm{N}$., lat. $5^{\circ} 20^{\prime}$ W.) north of Ushant (Ile d'Ouessant). From Lumby (1935) with additional means supplied by Mr A. J. Lee.

surprising if we remember that much of the warm water flow into the English Channel in summer(i.e. Aug.-Sept.) appears to be concentrated on the southern side (Lumby, I925; Harvey, 1930; cf. also Dietrich, 1950). This area also shows a steadier trend than at the other two stations: it is not as coastal, and is less likely to be influenced by a flow of colder water in the winter (cf. Dietrich, 1950). 


\section{SUMMARY}

Mid-monthly values of sea surface and bottom temperature, I92I-59, have been derived graphically from the raw data for International Station Er, and annual and other means calculated. The results are presented graphically and in tables, and discussed briefly in relation to faunistic and other changes in the English Channel.

Comparison with data from other areas suggests that in the Western Channel the annual mean surface temperature has risen about $0.5^{\circ} \mathrm{C}$ in the last 50 years. At station EI the bottom temperature has also risen, about $0.25^{\circ} \mathrm{C}$ since the I920's. The steadiest rise, in both surface and bottom temperatures, seems to have taken place in the autumn months.

\section{REFERENCES}

Atkins, W. R. G. \& Jenkins, P. G., I952. Note on sea temperatures in the English Channel, I92I to 1949, and Plymouth sunshine and light. F. mar. biol. Ass. U.K., Vol. 31, pp. 327-33.

BowDEn, K. F., 1955. Physical oceanography of the Irish Sea. Fish Invest., Lond., Ser. 2, Vol. r8, No. 8, 67 pp.

COOPER, L. H. N., I958. Sea temperatures in Plymouth Sound. F. mar. biol. Ass. U.K., Vol. 37, pp. I-3.

CRISP, D. J. \& SOUTHWARD, A. J., I958. The distribution of intertidal organisms along the coasts of the English Channel. F. mar. biol. Ass. U.K., Vol. 37, pp. 157-208.

LE DANOIS, E., I923. Consequences des phénomènes hydrologiques sur la biologie des poissons comestibles. Rapport Atlantique, 1922. Rapp. Cons. Explor. Mer, Vol. 3I, pp. 30-3.

DIETRICH, G., I950. Die anomale Jahresschwankung des Wärmeinhalts im Englischen Kanal, ihre Ursachen und Auswirkungen. Dtsch. hydrogr. Z., Bd. 3, pp. 184-20I.

FoRD, E., I929. Herring investigations at Plymouth. V. The Plymouth winter fishery during the season 1927-28. F. mar. biol. Ass. U.K., Vol. I6, pp. I-24.

- 1933. An account of the herring investigations conducted at Plymouth during the years from I924 to I933. F. mar. biol. Ass. U.K., Vol. I9, pp. 305-84.

HARVEY, H. W., I923. Hydrographic features of the water in the neighbourhood of Plymouth during the years 1921 and 1922. F. mar. biol. Ass. U.K., Vol. I3, pp. 225-35.

— 1930. Hydrography of the mouth of the English Channel 1925-1928. F. mar. biol. Ass. U.K., Vol. 16, pp. 791-820.

KeMP, S., I938. Oceanography and the fluctuations in the abundance of marine animals. Rep. Brit. Ass. Adv. Sci., 1938, pp. 85-Ior.

Lumby, J. R., 1925. The salinity and water movements in the English Channel and Southern Bight during the period 1920-1923. Fish. Invest., Lond., Ser. 2, Vol. 7, No. 7, 37 pp.

Lumby, J. R., I935. Salinity and temperature of the English Channel. Estimation of mean values for the upper water layer over the 25-year period 1903 to 1927 . Fish. Invest., Lond., Ser. 2, Vol. 14, No. 3, 67 pp.

RUSSELL, F. S., I935. On the value of certain plankton animals as indicators of water movements in the English Channel and North Sea. F. mar. biol. Ass. U.K., Vol. 20, pp. 309-32. 
Russell, F. S., 1939. Hydrographical and biological conditions in the North Sea as indicated by plankton organisms. F. Cons. int. Explor. Mer, Vol. I4, pp. I71-92.

SMED, J., I952. Monthly anomalies of the surface temperature in the Celtic Sea during the years 1903-39 and 1946-50. Ann. biol., Copenhague, Vol. 8, pp. 58-62.

SOUTHWARD, A. J. \& CRISP, D. J., I954. Recent changes in the distribution of the intertidal barnacles Chthamalus stellatus Poli and Balanus balanoides L. in the British Isles. F. Anim. Ecol., Vol. 23, pp. 163-77.

- 1956. Fluctuations in the distribution and abundance of intertidal barnacles. F. mar. biol. Ass. U.K., Vol. 35, pp. 21 I-29. 